\title{
Antioxidant potential of root extracts of Panax ginseng and Panax notoginseng
}

\author{
Man Jin $\mathrm{In}^{1} \cdot$ Dong Chung Kim ${ }^{1}$ \\ 인삼(Panax ginseng)과 전칠삼(Panax notoginseng) 뿌리 추출물의 \\ 항산화능
}

인 만진 ${ }^{1} \cdot$ 김동청 ${ }^{1}$

Received: 5 October 2021 / Accepted: 25 October 2021 / Published Online: 31 December 2021

(C) The Korean Society for Applied Biological Chemistry 2021

\begin{abstract}
In vitro antioxidant potential of $30 \%(\mathrm{v} / \mathrm{v})$ ethanolic extracts from Panax ginseng and Panax notoginseng roots was investigated. The polyphenol contents of Panax ginseng and Panax notoginseng extracts were $10.3 \pm 0.3$ and $10.4 \pm 0.4 \mathrm{mg} / \mathrm{g}$ extract, respectively. The extracts of Panax ginseng and Panax notoginseng possessed an antioxidant potential in a concentrationdependent manner. $\mathrm{EC}_{50}$ values of Panax ginseng and Panax notoginseng extracts for cation radical, reducing power, and nitrite were $4.76 \pm 0.12$ and $6.24 \pm 0.14 \mathrm{mg} / \mathrm{mL}, 1.99 \pm 0.01$ and $3.13 \pm 0.05$ $\mathrm{mg} / \mathrm{mL}$, and $4.78 \pm 0.31$ and $3.52 \pm 0.10 \mathrm{mg} / \mathrm{mL}$, respectively.
\end{abstract}

Keywords Antioxidant $\cdot$ Panax ginseng $\cdot$ Panax notoginseng · Polyphenol

\section{서 론}

Panax 속의 식물로는 17여종이 알려져 있는데 그 중 인삼 (Panax ginseng C. A. Meyer)과 전칠삼(Panax notoginseng F.

\section{Dong Chung Kim $(\bowtie)$}

E-mail: kimde@chungwoon.ac.kr

${ }^{1}$ Department of Chemical Engineering, Chungwoon University, Incheon 22100, Republic of Korea

This is an Open Access article distributed under the terms of the Creative Commons Attribution Non-Commercial License (http://creativecommons org/licenses/by-nc/3.0/) which permits unrestricted non-commercial use, distribution, and reproduction in any medium, provided the original work is properly cited.
H. Chen)의 뿌리는 뛰어난 약리 효과로 인해 예부터 생약재로 널리 활용되고 있다[1]. 특히 인삼은 우리나라를 비롯한 동아시 아 지역에서 건강증진과 여러 질병의 예방과 치료를 위하여 사 용되고 있고, 그 뿌리에는 ginsenosides, polyacetylene계 화합물, phenolic 화합물, 그리고 산성다당체 등의 생리활성 성분이 다 량 함유되어 있다[2,3]. 또한, 인삼의 뿌리는 면역 증진, 기억력 개선, 피로 개선, 항암, 항바이러스, 항산화, 항염증, 혈당 저하 및 지방흡수 조절 등의 약리 효과를 나타낸다[4]. 전칠삼은 중 국 남서부 지방에서 주로 자라는 약용식물로 그 뿌리에는 polyacetylene계 화합물, sesquiterpene계 화합물, phenolic 화합 물, 식물성 sterol, 아미노산 및 다당체 등의 성분을 함유하고 있다[5]. 또한 전칠삼의 뿌리에는 혈전 용해, 혈소판 형성 억제, 간성상세포 활성 억제, 혈액순환 개선, 관상 혈류량 증가 및 조 혈모세포의 증식을 유도하는 약리효과가 있는 것으로 알려져 있 다[6,7].

인삼의 항산화 작용에 관한 연구로는 인삼 메탄올 추출물의 ethyl acetate 분획과 $50 \%$ 에탄올 추출물이 유리라디칼 소거활 성을 보이고[8,9], 인삼의 $80 \%$ 에탄올 추출물이 peroxy, hydroxy 및 superoxide 라디칼을 소거한다고 알려져 있다[10]. 또한, 인 삼의 $50 \%$ 및 $80 \%$ 에탄올 추출물이 지질의 과산화를 효과적으 로 억제한다고 보고된 바 있다[10,11]. 전칠삼의 항산화 효과로 는 전칠삼의 물 추출물이 유리 및 양이온 라디칼과 hydroxy 라 디칼을 소거한다고 알려져 있다[12,13]. 이처럼 인삼과 전칠삼 각각에 대해 다양한 항산화 활성이 보고되었지만 아질산염 소 거능과 같은 몇몇 항산화 활성에 대한 추가 연구가 필요하고, 특히 인삼과 전칠삼의 항산화 효과를 같은 조건에서 비교하여 항산화 소재로서의 가능성을 평가할 필요가 있다.

따라서 본 연구에서는 인삼과 전칠삼을 $30 \%(\mathrm{v} / \mathrm{v})$ 에탄올 수 용액으로 추출한 후 양이온라디칼 소거활성, 환원력 및 아질산 
염 소거활성을 추가로 확인함으로써 인삼과 전칠삼의 항산화 효 과에 관한 기존의 연구[8-13]를 보완하였고, 또한 인삼과 전칠 삼의 항산화 활성을 비교함으로써 항산화 소재로서의 용도를 확 대하는데 기여하고자 하였다.

\section{재료 및 방법}

\section{실험재료}

인삼은 국산(Woosin Industrial Co., Geumsan, Republic of Korea)을, 전칠삼은 중국산(Green Grass of Economic and Trade Co., Yanji, Jilin, China)을 구입하여 분쇄한 후 200 mesh sieve로 걸러서 사용하였다. Folin \& Ciocalteu's phenol reagent, gallic acid, 2,2'-azinobis-(3-ethyl-benzothiazoline)sulfonic acid (ABTS), ferric chloride, potassium ferricyanide, sodium nitrite 및 L-ascorbic acid는 Sigma-Aldrich사(St. Louis, MO, USA)의 제품을, 그 외의 시약은 1 급 이상의 제품 을 사용하였다.

\section{인삼과 전칠삼의 추출 및 폴리페놀 함량}

인삼과 전칠삼의 분말에 $30 \%(\mathrm{v} / \mathrm{v})$ 에탄올 수용액을 10 배 $(\mathrm{w} / \mathrm{v})$ 가하고 $50{ }^{\circ} \mathrm{C}$ 의 항온진탕조에서 2시간 추출한 후 원심분리 $(3,000 \times \mathrm{g}, 10$ 분 $)$ 하여 상등액을 취하고 여과지로 걸러서 인삼과 전칠삼 추출물을 얻었다.

인삼과 전칠삼의 $30 \%$ 에탄올 추출물의 폴리페놀 함량을 확 인하기 위해 10 배 $(\mathrm{w} / \mathrm{v})$ 희석된 Folin \& Ciocalteu's phenol 용 액에 인삼과 전칠삼 추출물을 첨가하여 실온에서 5 분 반응시킨 다음 $10 \%(\mathrm{w} / \mathrm{v})$ sodium carbonate 용액을 가하고 실온에서 1 시간 정치한 후 $725 \mathrm{~nm}$ 의 흡광도를 측정하였다[14].

\section{인삼과 전칠삼 추출물의 항산화 활성}

인삼과 전칠삼의 $30 \%$ 에탄올 추출물의 $\mathrm{ABTS}$ 양이온라디칼 소 거활성을 확인하기 위해 $\mathrm{ABTS}$ 용액 $(7.5 \mathrm{mM} \mathrm{ABTS}+2.5 \mathrm{mM}$ potassium persulfate)을 만들어 어두운 곳에서 15시간 방치한 다음 $414 \mathrm{~nm}$ 에서의 흡광도가 $1.500 \pm 0.100$ 이 되게 희석하여 얻 어진 $\mathrm{ABTS}$ 용액에 인삼과 전칠삼 추출물을 첨가하여 실온에 서 90 분 반응시킨 후 $414 \mathrm{~nm}$ 의 흡광도를 측정하였다[15]. ABTS 양이온라디칼 소거활성(\%)은 [1-(실험군의 흡광도/대조군 의 흡광도) $] \times 100$ 으로 계산하였다.

인삼과 전칠삼의 $30 \%$ 에탄올 추출물의 환원력을 확인하기 위해 $0.2 \mathrm{M}$ phosphate 완충용액 $(\mathrm{pH}$ 6.86)에 인삼과 전칠삼 추 출물을 넣고 $1 \%$ potassium ferricyanide를 혼합하여 $50{ }^{\circ} \mathrm{C}$ 에서 20 분 반응시킨 다음 반응액에 $10 \%$ trichloroacetic acid를 처리 하여 원심분리 $(3,000 \times \mathrm{g}, 10$ 분 $)$ 한 후 상등액을 얻고 $0.1 \%$ ferric chloride를 넣어 $700 \mathrm{~nm}$ 의 흡광도를 측정하였다[16]. 환원력은
추출물의 농도에 따른 흡광도의 변화로 확인하였다.

인삼과 전칠삼의 $30 \%$ 에탄올 추출물의 아질산염 소거활성을 확인하기 위해 $0.2 \mathrm{M}$ citric acid 완충용액( $\mathrm{pH} 1.2$ )에 인삼과 전 칠삼 추출물을 넣고 $1 \mathrm{mM}$ sodium nitrite을 혼합하여 $37^{\circ} \mathrm{C}$ 에 서 1 시간 반응시킨 다음 $2 \%$ acetic acid와 Griess 시약을 차례 로 첨가하여 실온에서 15 분 정치시킨 후 $520 \mathrm{~nm}$ 의 흡광도를 측 정하였다[17]. 아질산염 소거활성 $(\%)$ 은 [1-(실험군의 흡광도/대 조군의 흡광도) $] \times 100$ 으로 계산하였다.

항산화 활성의 실험 결과는 Excel 2010 (Microsoft Co., Redmond, WA, USA)으로 분석하여 평균 \pm 표준편차로 나타내 었고, 인삼과 전칠삼 추출물 간의 항산화 활성의 차이에 대한 통계적 유의성은 t-test를 통해 검정하였다 $(p<0.05)$.

\section{결과 및 고찰}

식품산업의 주된 용매인 물과 에탄올의 혼합비율을 달리한 0 , $30,50,70$ 및 $100 \%(\mathrm{v} / \mathrm{v})$ 에탄올 수용액으로 인삼과 전칠삼의 뿌리를 추출하였고, 인삼과 전칠삼 모두 $30 \%$ 에탄올 추출물에 서 가장 높은 폴리페놀 함량을 나타내어 이를 대상으로 항산화 능을 확인하였다. 인삼과 전칠삼의 $30 \%$ 에탄올 추출물의 수율 은 각각 $36.2 \pm 0.5 \%$ 와 $30.2 \pm 1.7 \%$ 로 나타나 인삼의 수율이 다소 높았다(Table 1). 인삼과 전칠삼 추출물의 총 폴리페놀 함량은 각각 $10.3 \pm 0.3$ 및 $10.4 \pm 0.4 \mathrm{mg}$ gallic acid equivalents (GAE)/ $\mathrm{g}$-추출물로 거의 비슷한 함량을 보여주었다(Table 1). 식물에서 항산화 활성을 비롯한 다양한 생리활성의 근원이 되는 대표적 인 물질로 폴리페놀 화합물이 널리 알려져 있다[18]. 인삼과 전 칠삼 추출물의 폴리페놀 함량은 모시잎 추출물의 $105.0 \mathrm{mg} / \mathrm{g}$ [19], 두충잎 추출물의 $64.1 \mathrm{mg} / \mathrm{g}$ [20], 맥문동 잎 추출물의 174.2 $\mathrm{mg} / \mathrm{g}$ [21], 연잎 추출물의 $186.2 \mathrm{mg} / \mathrm{g}$ [22] 등 식물의 잎 추출 물보다는 크게 낮았으나, 와송 뿌리 추출물의 $1.7 \mathrm{mg} / \mathrm{g}$ [23], 맥 문동 뿌리 추출물의 $3.9 \mathrm{mg} / \mathrm{g}$ [21] 등 다른 식물의 뿌리 추출 물에 비해서는 높게 나타났다. 일반적으로 식물의 생리활성 성 분과 그 함량은 부위에 따라 차이가 크게 있는데[24], 여러 약 용식물을 부위별로 추출하여 폴리페놀 함량을 비교한 결과에서 도 뿌리에서 낮고 잎과 껍질에서 높게 나타났다[25]. 인삼과 와 송의 부위별 에탄올 추출물에서도 폴리페놀 함량이 잎, 줄기, 뿌리 순으로 뿌리 부위가 가장 낮았다[9,23]. 또한 추출물의 폴 리페놀 함량은 추출용매의 극성에 따라 달라지는데 전칠삼의 경 우 물 추출물에서는 $2.8 \mathrm{mg} / \mathrm{g}$ [13], 에탄올 추출물에서는 8.58 $\mathrm{mg} / \mathrm{g}$ [26]로 나타나 본 연구의 전칠삼의 $30 \%$ 에탄올 추출물의 폴리페놀 함량 $(10.4 \mathrm{mg} / \mathrm{g})$ 이 더 높았다. 본 연구에서 인삼과 전 칠삼 모두 $30 \%(\mathrm{v} / \mathrm{v})$ 에탄올 수용액 추출 시 폴리페놀 함량이 가장 높게 나타났는데, 이는 식물체를 물이나 에탄올로 추출할 때보다 두 용매가 혼합된 에탄올 수용액으로 추출 시 극성과

Table 1 Yield and polyphenol content of 30\% ethanolic extracts of Panax ginseng and Panax notoginseng roots

\begin{tabular}{cccc}
\hline & Yield (\%) & \multicolumn{2}{c}{ polyphenol content ${ }^{2)}(\mathrm{mg}$ GAE/g) } \\
\hline Panax ginseng & Panax notoginseng & Panax ginseng & Panax notoginseng \\
\hline $36.2 \pm 0.5^{1)}$ & $30.2 \pm 1.7^{1)}$ & $10.3 \pm 0.3^{1)}$ & $10.4 \pm 0.4^{1)}$ \\
\hline
\end{tabular}

${ }^{1)}$ Data represented means and SD of triplicate measurements

${ }^{2)}$ Polyphenol contents were expressed as gallic acid equivalents (GAE) 
(A)

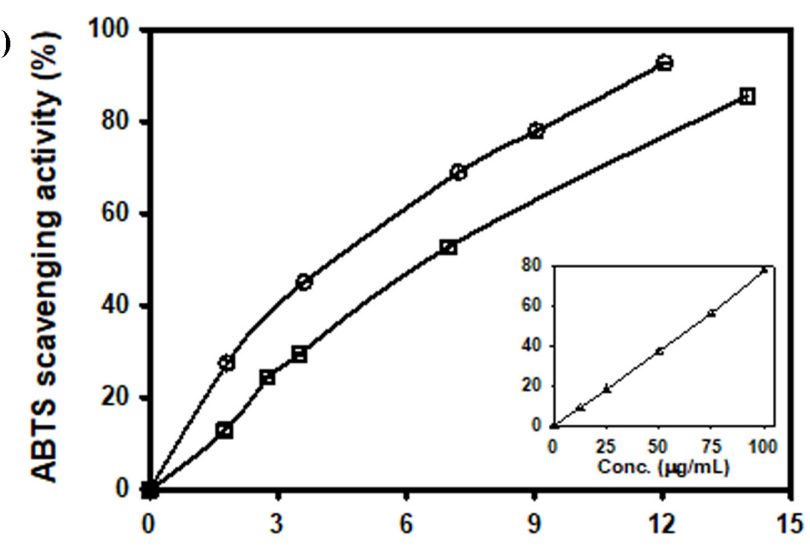

(B)

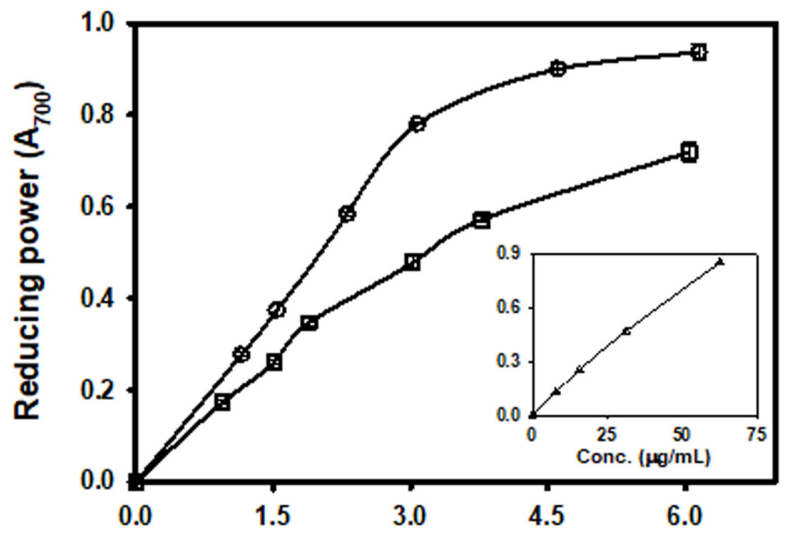

(C)

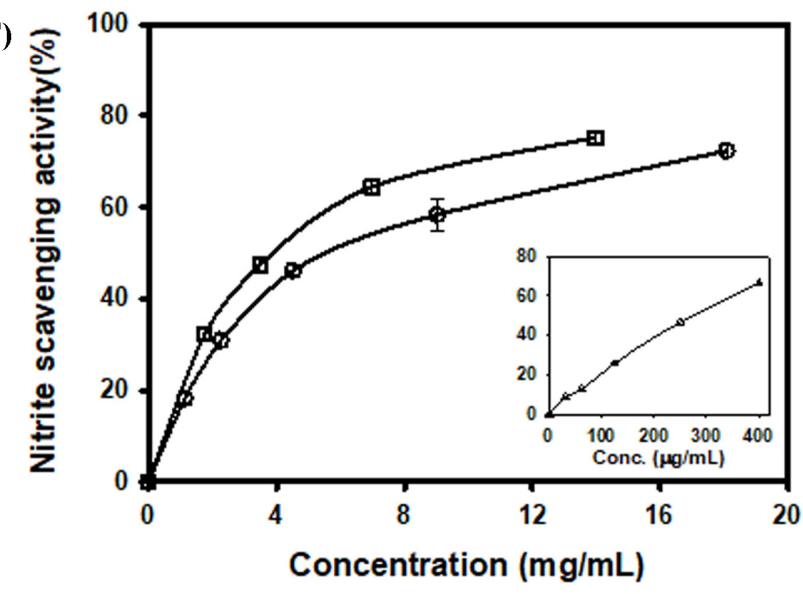

Fig. 1 Antioxidant activities of 30\% ethanolic extracts from Panax ginseng and Panax notoginseng roots. ABTS cation radical scavenging activity (A), reducing power (B), and nitrite scavenging activity (C) of Panax ginseng (-O-) and Panax notoginseng (- $\square$-) extracts. Insets were antioxidant activities of L-ascorbic acid as a positive control. Data were means and SD of triplicate measurements

비극성의 폴리페놀을 동시에 얻을 수 있을 뿐만 아니라 세포막 을 통한 용액의 침투와 이동이 용이하여 추출물의 폴리페놀 함 량이 증가하는 것으로 여겨진다[19,20,22,27].

인삼과 전칠삼의 $30 \%$ 에탄올 추출물은 $\mathrm{ABTS}$ 양이온라디칼 을 농도에 비례하여 소거하였다(Fig. 1A). ABTS 양이온라디칼
을 절반 소거하는 농도인 $\mathrm{EC}_{50}$ 값은 인삼 추출물이 $4.76 \pm 0.12$ $\mathrm{mg} / \mathrm{mL}$ 이었고, 전칠삼 추출물이 $6.24 \pm 0.14 \mathrm{mg} / \mathrm{mL}$ 로 나타나 인 삼 추출물의 양이온라디칼 소거활성이 다소 우수하였다 $(p<0.05$, Table 2). 대조물질인 L-ascorbic acid의 ABTS 양이온라디칼에 대한 $\mathrm{EC}_{50}$ 값은 $66.4 \pm 2.1 \mu \mathrm{g} / \mathrm{mL}$ 로 나타나(Table 2), 인삼과 전칠 삼 추출물의 양이온라디칼 소거능은 L-ascorbic acid에 비해서 는 크게 낮았으나 인삼과 전칠삼 추출물은 단일 성분이 아니라 다당체 등의 다양한 성분이 다량 함유된 혼합물이고 폴리페놀 함량이 낮은 것을 감안하면 양이온라디칼 소거능이 우수하다고 볼 수 있다. 기존의 연구에서도 두충잎 추출물은 폴리페놀 함 량이 $64.1 \mathrm{mg} / \mathrm{g}$ 에 $\mathrm{ABTS}$ 라디칼소거에 대한 $\mathrm{EC}_{50}$ 값이 $560.6 \mu \mathrm{g} / \mathrm{mL}$ [20]이었고, 연잎 추출물은 폴리페놀 함량이 186.2 $\mathrm{mg} / \mathrm{g}$ 에 $\mathrm{ABTS}$ 라디칼에 대한 $\mathrm{EC}_{50}$ 값이 $274.1 \mu \mathrm{g} / \mathrm{mL}$ [22]로 나 타나 추출물의 폴리페놀 함량에 비례하여 양이온라디칼 소거능 이 증가함을 알 수 있었다. 인삼의 메탄올 추출물과 전칠삼의 물 추출물도 $\mathrm{mg} / \mathrm{mL}$ 수준에서 $\mathrm{DPPH}$ 유리라디칼을 소거하는 것 $[8,12]$ 으로 나타나 본 연구의 $\mathrm{ABTS}$ 양이온라디칼 소거능과 비 슷하였다. 특히 전칠삼 물 추출물은 $10 \mathrm{mg} / \mathrm{mL}$ 에서 $\mathrm{ABTS}$ 양이 온라디칼을 $52.4 \%$ 소거한다고 보고[13]하였는데 본 연구의 전 칠삼의 $30 \%$ 에탄올 추출물이 $6.24 \mathrm{mg} / \mathrm{mL}$ 에서 $\mathrm{ABTS}$ 양이온라 디칼을 $50 \%$ 소거하는 것에 비해 활성이 낮은 수준이었다. 이 는 추출용매의 극성 차이로 인해 추출물의 폴리페놀 함량이 달 라지고 이에 따라 항산화 활성에서도 차이가 나타나는 것으로 볼 수 있다.

인삼과 전칠삼의 $30 \%$ 에탄올 추출물의 농도에 비례하여 환 원력이 증가하였다(Fig. 1B). 반응액의 흡광도가 0.500 에 이르 는데 필요한 농도인 $\mathrm{EC}_{50}$ 값은 인삼 추출물이 $1.99 \pm 0.01 \mathrm{mg} / \mathrm{mL}$ 이었고, 전칠삼 추출물이 $3.13 \pm 0.05 \mathrm{mg} / \mathrm{mL}$ 로 나타나 인삼 추출 물의 환원력이 다소 우수하였다 $(p<0.05$, Table 2$)$. 기존의 식물 의 잎 추출물의 항산화 연구에서 두충잎 추출물은 폴리페놀 함 량이 $64.1 \mathrm{mg} / \mathrm{g}$ 에 환원력의 $\mathrm{EC}_{50}$ 값이 $319.96 \mu \mathrm{g} / \mathrm{mL}$ [20]이었고, 연잎 추출물은 폴리페놀 함량이 $186.2 \mathrm{mg} / \mathrm{g}$ 에 환원력의 $\mathrm{EC}_{50}$ 값 이 $238.1 \mu \mathrm{g} / \mathrm{mL}$ [22]으로 나타나 환원력 역시 추출물의 폴리페 놀 함량에 비례함을 보여준다. 대조물질인 L-ascorbic acid의 환 원력의 $\mathrm{EC}_{50}$ 값이 $35.4 \pm 1.6 \mu \mathrm{g} / \mathrm{mL}$ (Table 2)인 것에 비해 인삼 과 전칠삼 추출물의 환원력은 낮았으나, 뿌리 추출물로서 항산 화 활성이 우수하다고 보고된 삼채 뿌리 에탄올 추출물의 환원 력 $\left(\mathrm{EC}_{50}=3.22 \mathrm{mg} / \mathrm{mL}\right)$ [28]과 비교하였을 때 인삼과 전칠삼의 뿌리 추출물의 환원력은 우수하다고 여겨진다.

인삼과 전칠삼의 $30 \%$ 에탄올 추출물은 발암성 nitrosamine의 원인 물질인 아질산염을 농도의존적으로 소거하였다(Fig. 1C). 아질산염을 절반 소거하는 농도인 $\mathrm{EC}_{50}$ 값은 인삼 추출물 $4.78 \pm 0.31 \mathrm{mg} / \mathrm{mL}$, 전칠삼 추출물 $3.52 \pm 0.10 \mathrm{mg} / \mathrm{mL}$ 로 나타나 전칠삼 추출물의 아질산염 소거능이 다소 우수하였고 $(p<0.05)$, 대조물질인 L-ascorbic acid의 아질산염에 대한 $\mathrm{EC}_{50}$ 값은 $304.9 \pm 18.6 \mu \mathrm{g} / \mathrm{mL}$ 로 나타났다(Table 2). 인삼과 전칠삼 추출물 의 아질산염 소거능은 L-ascorbic acid에 비해서는 크게 낮았으 나 생리활성 부위가 뿌리이고 아질산염 소거능이 우수하다고 알 려진 삼채 뿌리의 에탄올 추출물의 아질산염에 대한 $\mathrm{EC}_{50}$ 값 $(4.27 \mathrm{mg} / \mathrm{mL})$ [28]과 비슷하거나 낮은 수준으로 나타나 인삼과 전칠삼 뿌리 추출물의 아질산염 소거능은 우수하다고 판단된다. 또한 아질산염에 대한 $\mathrm{EC}_{50}$ 값을 폴리페놀 함량이 높은 잎 추출 
Table 2 Antioxidant potential of 30\% ethanolic extracts from Panax ginseng and Panax notoginseng roots

\begin{tabular}{llcc}
\hline \hline \multirow{2}{*}{ Antioxidant effects } & \multicolumn{3}{c}{$\mathrm{EC}_{50}$ values $(\mu \mathrm{g} / \mathrm{mL})^{1)}$} \\
\cline { 2 - 4 } & Panax ginseng & Panax notoginseng & L-ascorbic acid $^{2)}$ \\
\hline Cation radical scavenging activity ${ }^{3)}$ & $4,762.8 \pm 118.8^{*}$ & $6,240.5 \pm 143.0^{*}$ & $66.4 \pm 2.1$ \\
Reducing power $^{4}$ & $1,988.1 \pm 8.9^{*}$ & $3,128.2 \pm 52.5^{*}$ & $35.4 \pm 1.6$ \\
Nitrite scavenging activity $^{3)}$ & $4,776.6 \pm 310.1^{*}$ & $3,524.6 \pm 96.7^{*}$ & $304.9 \pm 18.6$ \\
\hline
\end{tabular}

${ }^{10}$ Data represented means and SD of triplicate measurements. Significantly different between Panax ginseng and Panax notoginseng by t-test $(* p<0.05)$

${ }^{2)} \mathrm{L}-\mathrm{ascorbic}$ acid was used as a positive control

${ }^{3)} \mathrm{EC}_{50}$ values for cation radical and nitrite are expressed as the concentrations at which $50 \%$ of ABTS radical and nitrite were scavenged, respectively

${ }^{4)} \mathrm{EC}_{50}$ values for reducing power are expressed as the concentrations at which the absorbance was 0.500

물인 두충잎 추출물 $2.33 \mathrm{mg} / \mathrm{mL}$ [20], 연잎 추출물 $0.58 \mathrm{mg} / \mathrm{mL}$ [22], 약쑥 추출물 $0.98 \mathrm{mg} / \mathrm{mL}$ [29]과 비교해 보아도 인삼과 전 칠삼은 뿌리 추출물로서 폴리페놀 함량이 낮다는 것을 고려하 면 인삼과 전칠삼 추출물의 아질산염 소거활성은 우수하다고 여 겨진다.

이상의 결과에서 인삼과 전칠삼의 $30 \%$ 에탄올 추출물은 10 $\mathrm{mg} / \mathrm{g}$ 수준의 폴리페놀을 함유하고 있었고 ABTS 양이온라디칼 소거능, 환원력 및 아질산염 소거능의 항산화 능력을 나타내었 다. 향후 인삼과 전칠삼 추출물의 항산화 성분을 분리하여 비 교하고 항산화 활성의 메커니즘을 규명하는 연구가 필요할 것 으로 여겨진다.

\section{초록}

인삼(Panax ginseng)과 전칠삼(Panax notoginseng)의 $30 \%(\mathrm{v} / \mathrm{v})$ 에탄올 추출물의 항산화 활성을 확인하였다. 인삼과 전칠삼 추 출물의 폴리페놀 함량은 각각 $10.3 \pm 0.3$ 및 $10.4 \pm 0.4 \mathrm{mg} / \mathrm{g}$-추출 물이었다. 인삼과 전칠삼 추출물은 농도의존적으로 항산화 활성 을 나타내었다. 인삼과 전칠삼 추출물의 양이온라디칼에 대한 $\mathrm{EC}_{50}$ 값은 $4.76 \pm 0.12$ 및 $6.24 \pm 0.14 \mathrm{mg} / \mathrm{mL}$ 이었고, 환원력에 대한 $\mathrm{EC}_{50}$ 값은 $1.99 \pm 0.01$ 및 $3.13 \pm 0.05 \mathrm{mg} / \mathrm{mL}$ 이었으며, 아질산염에 대한 $\mathrm{EC}_{50}$ 값은 $4.78 \pm 0.31$ 및 $3.52 \pm 0.10 \mathrm{mg} / \mathrm{mL}$ 이었다.

Keywords 인삼(Panax ginseng) · 전칠삼(Panax notoginseng) 폴리페놀 · 항산화

감사의 글 본 연구는 2021학년도 청운대학교 학술연구조성비 지원에 의해 수행된 것입니다.

\section{References}

1. Zhang H, Abid S, Ahn JC, Mathiyalagan R, Kim YJ, Yang DC, Wang Y (2020) Characteristics of Panax ginseng cultivars in Korea and China. Molecules 25: 2635. doi: 10.3390/molecules25112635

2. In MJ, Chae HJ, Kim DC (2014) In vitro antioxidant and anticancer potential of n-hexane extract from ginseng marc. J Appl Biol Chem 57: 247-250. doi: 10.3839/jabc.2014.039

3. Lee SD, Yoo G, Chae HJ, In MJ, Oh NS, Hwang YK, Hwang WI, Kim DC (2009) Lipid-soluble extracts as the main source of anticancer activity in ginseng and ginseng marc. J Am Oil Chem Soc 86: 10651071. doi: $10.1007 / \mathrm{s} 11746-009-1460-\mathrm{x}$

4. Attele AS, Wu JA, Yuan CS (1999) Ginseng pharmacology: multiple constituents and multiple actions. Biochem Pharmacol 58: 1685-1693. doi: 10.1016/s0006-2952(99)00212-9

5. Yang W, Qiao X, Li K, Fan J, Bo T, Guo D, Ye M (2016) Identification and differentiation of Panax ginseng, Panax quinquefolium, and Panax notoginseng by monitoring multiple diagnostic chemical markers. Acta Pharm Sin B 6: 568-575. doi: 10.1016/j.apsb.2016.05.005

6. Yang X, Xiong X, Wang H, Wang J (2014) Protective effects of Panax notoginseng sponins on cardiovascular diseases: a comprehensive overview of experimental studies. Evid Compl Altern Med 2014: 204840. doi: $10.1155 / 2014 / 204840$

7. Ng TB (2006) Pharmacological activity of sanchi ginseng (Panax notoginseng). J Pharm Pharmacol 58: 1007-1019. doi: 10.1211/jpp.58.8. 0001

8. Kim JS, Moon GS, Kim HO, Lee YS (2007) Antioxidant properties of ginseng (P. ginseng C.A. Meyer) extracts by organic solvent fractionation. J Food Sci Nutr 12: 267-272. doi: 10.3746/jfn.2007.12.4.267

9. Lee SE, Lee SW, Bang JK, Yu YJ, Seong NS (2004) Antioxidant activities of leaf, stem and root of Panax ginseng C.A. Meyer. Korean J Medicinal Crop Sci 12: 237-242

10. Kim SH, Kim YM (2007) Determination of the antioxidant capacity of Korean ginseng using an ORAC assay. J East Asian Soc Dietary Life 17: 393-401

11. Kim MJ, Kwon RH, Jang MW, Ha BJ (2012) Antioxidant and antiwrinkle effects of steamed three ginseng extracts. J Soc Cosmet Scientists Korea 38: 155-162. doi: 10.15230/SCSK.2012.38.2.155

12. Xiong Y, Chen L, Man J, Hu Y, Cui X (2019) Chemical and bioactive comparison of Panax notoginseng root and rhizome in raw and steamed forms. J Ginseng Res 43: 385-393. doi: 10.1016/j.jgr.2017.11.004

13. Wang Y, Kim ES, Lee JA (2018) The study of antioxidant and antiinflammatory effects of notoginseng root (NGR) hot water extracts. J Kor Soc Cosm 24: 1014-1020

14. Folin O, Denis W (1912) On phosphotungstic-phosphomolybdic compounds as color reagents. J Biol Chem 12: 239-243. doi: 10.1016/ S0021-9258(18)88697-5

15. Re R, Pellegrini N, Proteggente A, Pannala A, Yang M, Rice-Evans C (1999) Antioxidant activity applying an improved ABTS radical cation decolorization assay. Free Radical Biol Med 26: 1231-1237. doi: 10.1016/S0891-5849(98)00315-3

16. Oyaizu M (1985) Studies on products of browning reaction: antioxidant activities of products of browning reaction prepared from glucosamine. Jap J Nutr 44: 307-315. doi: 10.5264/eiyogakuzashi.44.307

17. Gray JI, Dugan Jr LR (1975) Inhibition of N-nitrosamine formation in model food system. J Food Sci 40: 981-985. doi: 10.1111/j.1365-2621. 1975.tb02248.x

18. Ardestani A, Yazdanparast R (2007) Antioxidant and free radical scavenging potential of Achillea santolina extracts. Food Chem 104: 2129. doi: $10.1016 /$ j.foodchem.2006.10.066

19. Kim C, In MJ, Kim DC (2015) In vitro antioxidant activity of ethanol extract from Boehmeria nivea L. leaves. Food Eng Prog 19: 76-81. doi: 10.13050/foodengprog.2015.19.1.76

20. Kim DC (2020) Antioxidative activities of ethanolic extracts of Duzhong 
(Eucommia ulmoides Oliver) leaf and bark. J Appl Biol Chem 63: 259 265. doi: $10.3839 /$ jabc. 2020.035

21. Seo SJ, Kim NW (2010) Physiological activities of leaf and root extracts from Liriope platyphylla. Korean J Food Preserv 17: 123-130

22. Park EJ, Cho HW, Park YJ, In MJ, Kim DC (2021) In vitro biological activities of lotus (Nelumbo nucifera) leaves extract. J Appl Biol Chem 64: 121-125. doi: 10.3839/jabc.2021.018

23. Lee SJ, Song EJ, Lee SY, Kim KBWR, Kim SJ, Yoon SY, Lee CJ, Ahn DH (2009) Antioxidant activity of leaf, stem and root extracts from Orostachys japonicus and their heat and $\mathrm{pH}$ stabilities. J Korean Soc Food Sci Nutr 38: 1571-1579. doi: 10.3746/jkfn.2009.38.11.1571

24. Lee SH, Jin YS, Heo SI, Shim TH, Sa JH, Choi DS, Wang MH (2006) Composition analysis and antioxidative activity from different organs of Cirsium setidens Nakai. Korean J Food Sci Technol 38: 571-576

25. Moon JS, Kim SJ, Park YM, Hwang IS, Kim EH, Park JW, Park IB, Kim SW, Kang SG, Park YK, Jung ST (2004) Antimicrobial effect of methanol extracts from some medicinal herbs and the content of phenolic compounds. Korean J Food Preserv 11: 207-213

26. Choi SY, Lim SH, Kim JS, Ha TY, Kim SR, Kang KS, Hwang IK (2005) Evaluation of the estrogenic and antioxidant activity of some edible and medicinal plants. Korean J Food Sci Technol 37: 549-556

27. Kim DS, Choi MH, Shin HJ (2018) Polyphenol contents and antioxidant activities of domestic bamboo leaves with different extraction solvents. J Adv Eng Tech 11: 7-13. doi: 10.35272/jaet.2018.11.1.7

28. Zhang C, Tong T, Kim CK, Liu Y, Seo HJ, Kim BS, Kang SG (2015) Antioxidant and anti-inflammatory properties of extracts from Allium hookeri root. Korean J Food Preserv 22: 867-877. doi: 10.11002/ kjfp.2015.22.6.867

29. In MJ, Kim KH, Kim DC (2020) Antioxidant and anticoagulant activities of Ganghwa medicinal mugwort (Artemisia princeps Pampanini) extract. J Appl Biol Chem 63: 439-442. doi: 10.3839/ jabc.2020.057 